\title{
The Mercator-Hondius Atlas at the Donner Institute
}

$\mathrm{T}$ his introduction describes the background to, and reasons why, the Mercator-Hondius Atlas analysed in this issue of Approaching Religion became part of the library collection of the Donner Institute.

IN 2008, THE BOOK CONSERVATOR of Åbo Akademi University Library, Mait Luik, contacted me. I was at the time Chief Librarian at this library and simultaneously Director of the Donner Institute for Research in Religious and Cultural History, also based in Turku. Luik's concern was as follows: he had recently visited Nordiska antikvariatet (the Nordic Antiquarian Bookshop) in Helsinki and there, engaged in conversation with its manager Cecil Hagelstam, whom he knew from before. Thus, he had learnt that Hagelstam was interested in selling a copy of the Mercator-Hondius Atlas, which he had in his possession and which he now informed me about.

At this point, neither my closest colleagues nor I knew anything about the Mercator-Hondius Atlas - but we swiftly made investigations into the matter. We noted that this atlas was not available in any other

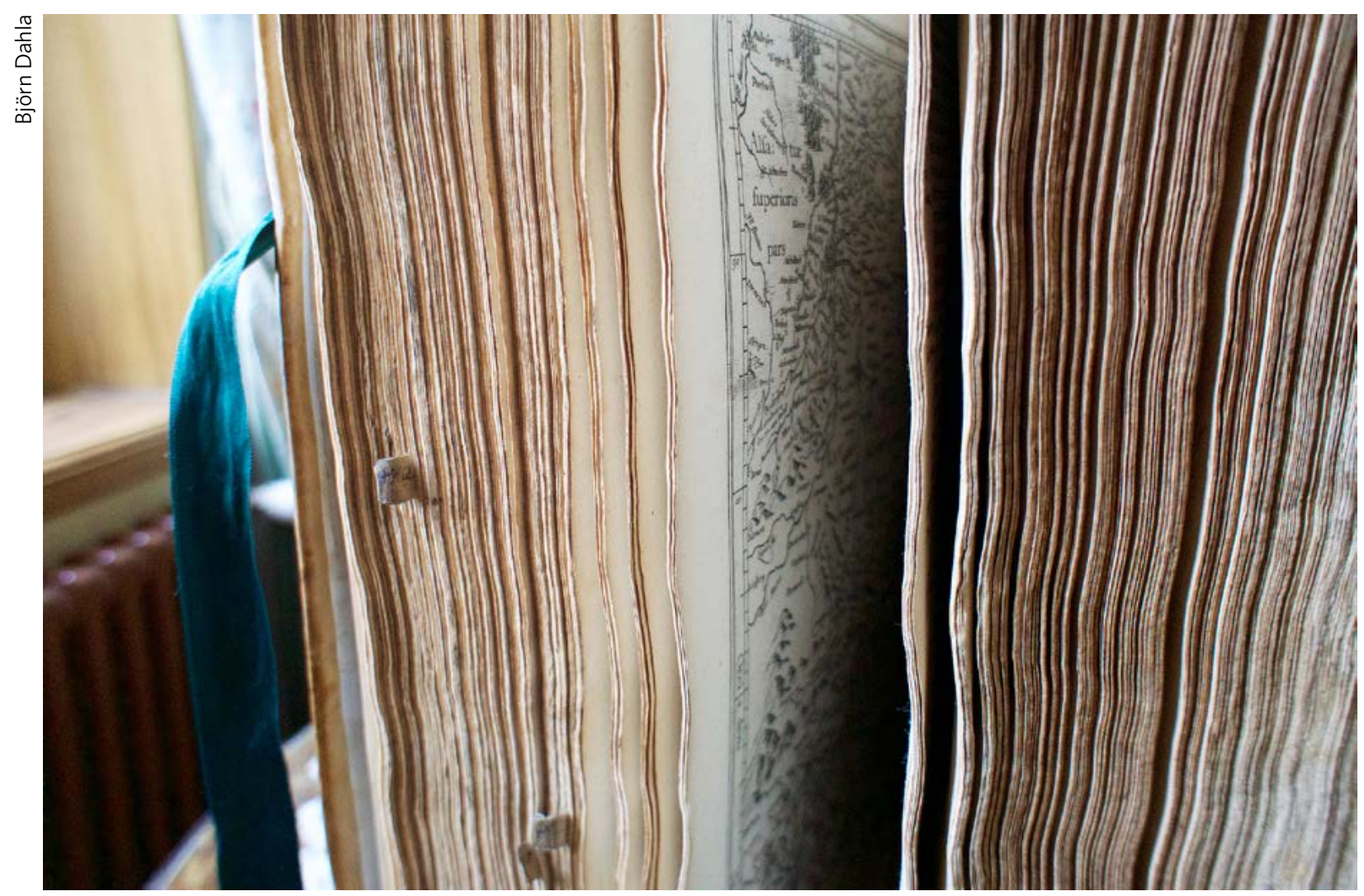


Nordic country, and this increased our interest in the copy on sale. After this, Cecil Hagelstam and Mait Luik visited me in Turku, and Hagelstam brought the atlas with him.

The atlas was in excellent condition - all the pages were preserved and the condition of the paper was immaculate. By contrast, it can be noted that the destiny of many historic atlases has not been so favourable: often pages have been cut out, furnished with passepartouts and sold as objects of interior design. The only damage inflicted on this book during its 400-year lifespan was that the parchment of the cover had come apart over the spine, as the book had not been in the hands of a user in a very, very long time. Hence, the contact with oil from human hands needed to keep the parchment from drying and falling apart was lacking. However, Luik evaluated that he could restore the cover.

As mentioned above, I discussed the matter in great detail with my colleagues - above all with Marita Rajalin, who was at the time head of the Manuscript Collection of Åbo Akademi University Library and who was well acquainted with the rare books included in the library collections (in this context, rare books refers to manuscripts published before the year 1830). On the basis of our joint reasoning, the decision was taken to purchase the atlas.

At first, it was unclear whether the atlas would be placed at Åbo Akademi University Library or at the Donner Institute. Due to practical considerations it was eventually decided that the latter would acquire the atlas and include it in its collection. The Donner Institute is a private research institute whose library houses the largest collection on religion in the Nordic countries. It is related to Åbo Akademi University Foundation, which administers the bequest of Olly and Uno Donner to uphold the institute. It is located within Åbo Akademi University campus and integrated in the academic research milieu of this university.

The Mercator-Hondius Atlas is a rare pearl in a Finnish library Thus, it is with great delight I acknowledge that researchers and students from our neighbouring university, the University of Turku, now have devoted a great deal of effort and many hours to researching and investigating this atlas in a highly scholarly way. This confirms, in its own way, our conclusion that acquiring this atlas for Turku was the right decision.
Dr Tore Ahlbäck is docent of Comparative Religion at Åbo Akademi University. He is Director Emeritus of the Donner Institute and former Chief Librarian of Åbo Akademi University Library.

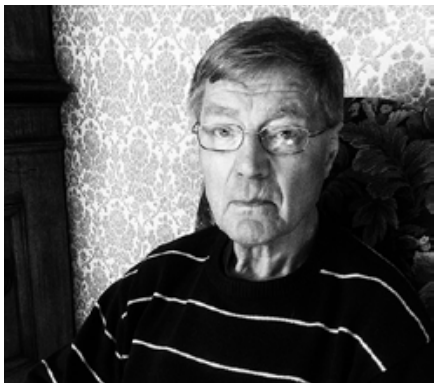

